\title{
EDUKASI PENYUSUNAN LAPORAN KEUANGAN UMKM MENGGUNAKAN APLIKASI LAMIKRO
}

\author{
Kodirin'); Alfiana Yuniarianti; Dheyvanza Arsy Akbar; Farhan Ferdiana; Fauzan Adima; Guruh Septiano \\ Putro; Hizkia Elhagios Bram; Mala Mastriani Astuti; Risma Trinur Pebriyanti; TK Salsabila; Widya \\ Kristina Simamora
}

1)kodirin@pknstan.ac.id, Politeknik Keuangan Negara STAN

\begin{abstract}
Government Regulation of the Republic of Indonesia Number 23 of 2018 concerning Income Tax on Income from Businesses Received or Obtained by Taxpayers with a Certain Gross Turnover mandates Micro, Small and Medium Enterprises (MSMEs) to prepare financial reports according to applicable standards within no later than 7 years. This is a problem for most MSMEs. The PKN STAN community service team integrated student work courses took the initiative to help overcome these problems by making video tutorial and educational posters for preparing financial reports using the Lamikro application. Video tutorial is uploaded on Youtube so that it can be used by MSMEs. Educational posters were handed over to Gene' Rent Car, South Tangerang MSME, and Gangsal Coffee and Drinks, Bandung MSME.
\end{abstract}

Keywords : MSMEs, Lamikro application, video tutorial, and educational posters

\begin{abstract}
Abstrak
Peraturan Pemerintah Republik Indonesia Nomor 23 Tahun 2018 tentang Pajak Penghasilan atas Penghasilan dari Usaha yang Diterima atau Diperoleh Wajib Pajak yang Memiliki Peredaran Bruto Tertentu mengamanatkan kepada Usaha Mikro, Kecil, dan Menengah (UMKM) untuk menyusun laporan keuangan sesuai standar yang berlaku dalam waktu paling lambat 7 tahun. Hal ini menjadi permasalahan bagi sebagian besar UMKM. Tim pengabdian kepada masyarakat PKN STAN terintegrasi kuliah kerja mahasiswa berinisiatif membantu mengatasi permasalahan tersebut dengan membuat video tutorial dan poster edukasi penyusunan laporan keuangan menggunakan aplikasi Lamikro. Video tutorial diunggah di Youtube agar bisa dimanfaatkan oleh UMKM. Poster edukasi diserahkan kepada Gene' Rent Car, UMKM Tangerang Selatan, dan Gangsal Coffee and Drinks, UMKM Bandung.
\end{abstract}

Kata Kunci : UMKM, aplikasi Lamikro, video tutorial, dan poster edukasi.

\section{PENDAHULUAN}

Perekonomian Indonesia ditopang oleh Usaha Mikro, Kecil, dan Menengah (UMKM). Dilaporkan oleh Kementerian Koperasi dan UKM RI bahwa pada tahun 2019 jumlah UMKM 65.465.497 unit atau 99,99\% dari total keseluruhan pelaku usaha di Indonesia. Tenaga kerja yang diserap oleh UMKM sebanyak 119.562.843 tenaga kerja atau 96,92\% dari tenaga kerja nasional. Sumbangan UMKM kepada produk domestik bruto (PDB) sebesar Rp9.580.762,7 miliar atau 60,51\% dari total PDB. UMKM melakukan investasi sebesar Rp2.619.382,0 miliar atau 60,03 dari total investasi nasional (Kemenkop UKM, 2021).

Namun, menurut Kemenkop UKM sebagian besar pelaku usaha mikro belum melakukan pencatatan transaksi keuangan dengan baik sesuai dengan standar yang berlaku (Kemenkop UKM, 2019). Secara umum, sebagian besar pelaku UMKM masih belum memahami akuntansi dan tidak membuat catatan untuk transaksi usahanya (www.kompas.com, 2018).

Peraturan Pemerintah Republik Indonesia Nomor 23 Tahun 2018 tentang Pajak Penghasilan atas Penghasilan dari Usaha yang Diterima atau Diperoleh Wajib Pajak yang Memiliki Peredaran Bruto Tertentu meminta UMKM untuk membuat laporan keuangan sesuai dengan standar akuntansi keuangan entitas mikro, kecil, dan menengah dalam waktu paling lambat 7 tahun untuk wajib pajak orang pribadi; badan berbentuk koperasi, persekutuan komanditer, atau firma; dan 3 tahun untuk wajib pajak badan berbentuk perseroan terbatas (PP No. 23, 2018).

Berdasarkan permasalahan tersebut, dilakukan kegiatan pengabdian kepada masyarakat yang terintegrasi dengan kegiatan kuliah kerja mahasiswa (KKM) untuk membantu mengatasi 
permasalahan tersebut dengan membuat video tutorial dan poster penyusunan laporan keuangan menggunakan aplikasi Lamikro. Aplikasi Lamikro dipilih karena aplikasi yang dibuat oleh Kementerian Koperasi dan UKM ini sederhana dan mudah digunakan (Kominfo, 2018).

\section{METODE}

Metode pengabdian kepada masyarakat yang dilakukan adalah penayangan video tutorial cara menggunakan aplikasi Lamikro di Youtube. Dengan menyimak video tutorial ini diharapkan pelaku UMKM bisa mendapat panduan untuk mengunduh apliasi, melakukan registrasi, dan menginput data transaksi serta membuat laporan keuangan sesuai dengan SAK EMKM. Aplikasi Lamikro dipilih karena sederhana dan mudah untuk digunakan, namun cukup memadai untuk usaha mikro atau pun usaha kecil dan menengah dengan transaksi usaha yang sederhana (Kominfo, 2018). Laporan keuangan yang dihasilkan berupa laporan laba rugi, laporan posisi keuangan, dan pernyataan kesesuaian laporan keuangan dengan SAK EMKM. Selain itu, Tim Pengmas membuat poster edukasi penyusunan laporan keuangan UMKM untuk memotivasi pelaku UMKM menggunakan aplikasi Lamikro.

Target keluaran kegiatan pengabdian disusun berdasarkan permasalahan yang sudah diidentifikasi. Target keluaran yang disusun oleh Tim Pengabdian kepada masyarakat disajikan pada Tabel 1. Jenis luaran dipilih oleh tim pengabdian kepada masyarakat, sedangkan indikator dan tolok ukur keberhasilan mengacu kepada Pedoman pelaksanaan kuliah kerja mahasiswa tahun akademik 2020/2021.

Tabel 1. Luaran dan Indikator Capaian

\begin{tabular}{|c|c|c|c|c|}
\hline No & Luaran & Kriteria & Indikator & $\begin{array}{c}\text { Tolok Ukur } \\
\text { Keberhasilan }\end{array}$ \\
\hline \multirow[t]{2}{*}{1} & $\begin{array}{l}\text { Video } \\
\text { tutorial }\end{array}$ & $\begin{array}{l}\text { - Durasi 5-10 menit } \\
\text { - Diunggah di Youtube } \\
\text { - Kualitas gambar baik } \\
\text { - Volume suara (narasumber) terdengar jelas } \\
\text { - Resolusi maksimal video 720p (HD) } \\
\text { - Rasio tampilan video 16:9 } \\
\text { - Ukuran file maksimal 150 MB } \\
\text { - Format MP4 } \\
\text { - Memenuhi standar audio } \\
\text { - Dapat menciptakan perhatian pemirsa }\end{array}$ & $\begin{array}{l}\text { Jumlah views } \\
\text { dan likes s.d. } \\
\text { tanggal } 17 \\
\text { September } 2021\end{array}$ & $\begin{array}{l}\text { Minimal } \\
\text { mendapatkan } 100 \\
\text { views dengan } 51 \\
\text { likes }\end{array}$ \\
\hline & $\begin{array}{l}\text { Poster } \\
\text { edukasi }\end{array}$ & $\begin{array}{l}\text { Kertas Ukuran A3 (Terdapat logo PKN STAN } \\
\text { dan KKM 2021) }\end{array}$ & $\begin{array}{l}\text { Penerima } \\
\text { manfaat spesifik } \\
\text { dan jelas }\end{array}$ & $\begin{array}{l}\text { Dokumentasi } \\
\text { penyerahan poster } \\
\text { kepada penerima } \\
\text { manfaat }\end{array}$ \\
\hline
\end{tabular}

Sumber: Tim Pengmas dan Pedoman Pelaksanaan KKM 2020-2021, diolah (2020)

Mengingat kondisi pandemi Covid 19 sepanjang tahun 2021, kegiatan pengabdian kepada masyarakat yang terintegrasi dengan kegiatan kuliah kerja mahasiswa dilaksanakan dengan meminimalkan interaksi secara langsung dengan mitra pengabdian. Kegiatan yang dilakukan dalam program pengabdian masyarakat ini berupa pembuatan video tutorial aplikasi Lamikro sebagai pemberdaya UMKM di era digital dan pembuatan poster aplikasi Lamikro sebagai pemberdaya UMKM di era digital. Video tutorial diunggah di Youtube sehingga bisa dimanfaatkan oleh UMKM untuk belajar menggunakan aplikasi Lamikro. Poster edukasi diberikan kepada dua UMKM yang Gene' Rent Car, UMKM di Tangerang Selatan dan Gangsal Coffee and Drinks, UMKM di Bandung untuk mendorong mereka menggunakan aplikasi Lamikro. Tahapan kegiatan yang dilakukan disajikan pada Tabel 2. 
Tabel 2. Tahapan Pelaksanaan Program

\begin{tabular}{lll}
\hline No & \multicolumn{1}{c}{ Tanggal } & \multicolumn{1}{c}{ Kegiatan } \\
\hline 1 & $1-7$ September & $\begin{array}{l}\text { Pembuatan video Tutorial Aplikasi Lamikro Sebagai Pemberdaya UMKM di Era } \\
\text { Digital dan poster Aplikasi LamikroSebagai Pemberdaya UMKM di Era Digital }\end{array}$ \\
\hline 2 & $\begin{array}{l}\text { 8-10 } \\
\text { September 2021 }\end{array}$ & $\begin{array}{l}\text { Mengunggah video Tutorial Aplikasi Lamikro Sebagai Pemberdaya UMKM di Era } \\
\text { Digital ke Youtube dan menyerahkan poster Aplikasi Lamikro Sebagai Pemberdaya } \\
\text { UMKM di Era Digital kepada Gene' Rent Car dan Gangsal Coffee and Drinks. }\end{array}$ \\
\hline
\end{tabular}

Sumber: Tim Pengmas (2020)

\section{HASIL DAN PEMBAHASAN}

\section{Video Tutorial}

Luaran pertama kegiatan pengabdian kepada masyarakat ini berupa video Tutorial Aplikasi Lamikro Sebagai Pemberdaya UMKM di Era Digital yang dunggah di Youtube pada tautan https://www.youtube.com/watch? $\mathrm{v}=\mathrm{x} 28 \mathrm{eShuAa} 48$. Jumlah views per tanggal 17 September sebanyak 237 (237\% dari target 100 views). Jumlah like per tanggal 17 September sebanyak 78 (156\% dari target 50 like). Tangkapan layar jumlah views dan like per tanggal 17 September disajikan pada Gambar 1.

\section{Gambar 1. Tampilan Video Tutorial di Youtube}

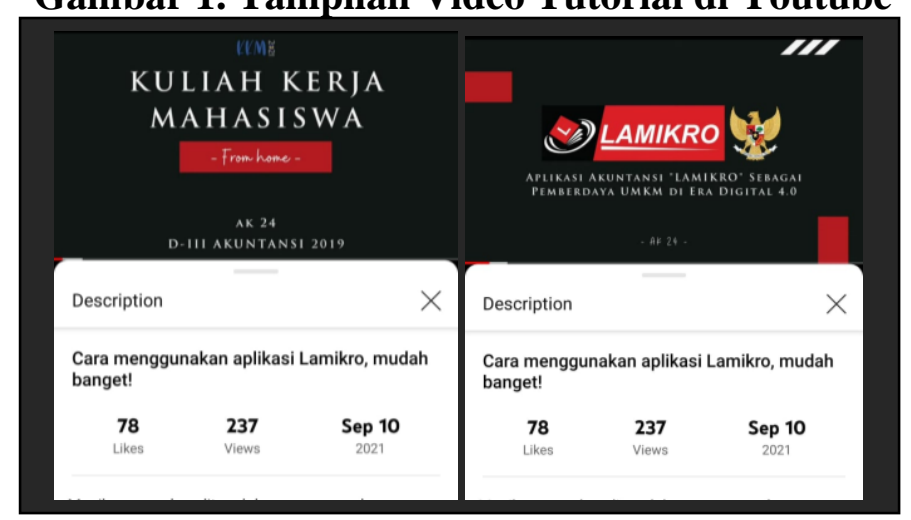

Sumber: Youtube (2021)

Materi video tutorial mulai dari cara mengunduh aplikasi Lamikro di telepon genggam, registrasi, cara menginput transaksi, sampai dengan mencetak laporan laba rugi dan laporan posisi keuangan. Aplikasi Lamikro diunduh melalui playstore di telepon genggam berbasis Android. Setelah aplikasi berhasil diunduh kemudian dibuka dan dilanjutkan dengan regsitrasi. Langkah awal ini bisa dilihat pada Gambar 2.

Gambar 2. Petunjuk Menginstal Aplikasi Lamikro

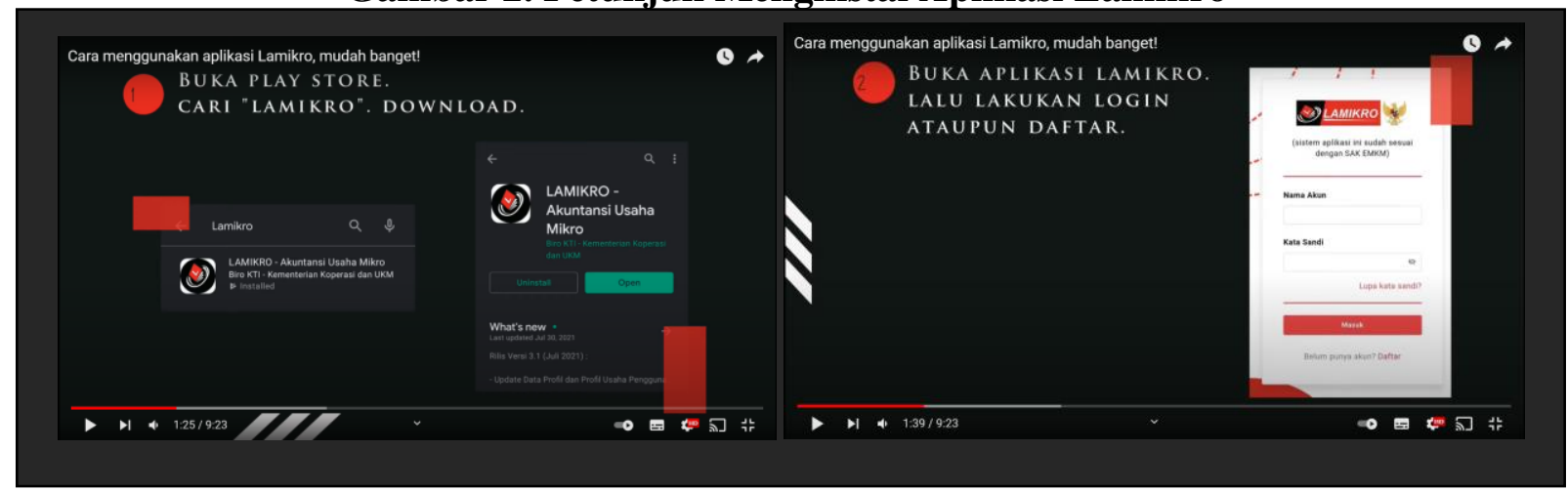

Sumber: Aplikasi Lamikro (2021) meliputi:

Registrasi penggunaan aplikasi Lamikro dilakukan dengan mengisi data yang diminta

- Nomor Induk Kependudukan (NIK)*

- Nama Lengkap* 


\section{PENGMASKU}

Volume 2 No. 1, 2022

- NPWP Pribadi

- Email*

- Nomor telepon/HP*

- Nama Usaha*

- Nomor Izin Usaha Mikro Kecil (IUMK) atau Nomor Induk Berusaha (NIB)

IUMK berupa satu lembar naskah sebagai tanda legalitas telah mendapatkan izin usaha mikro dan kecil. Pelaku usaha mikro dan kecil mendapat kepastian hukum dengan terbitnya IUMK sehingga diharapkan lebih berkembang usahanya (UKM Indonesia, n.d.-a). Nomor Induk Berusaha (NIB) merupakan identitas pelaku usaha dalam melaksaanakan kegiatan usaha sesuai dengan bidang usaha yang digeluti oleh UMKM (UKM Indonesia, n.d.-b).

- Alamat Usaha*

- Nama Akun*

- Kata Sandi*

Data yang bertanda * wajib diisi, sedangkan data yang tidak bertandang * bisa dilewati apabila belum memiliki. Tampilan isian data registrasi aplikasi Lamikro bisa dilihat pada Gambar 3.

Gambar 3. Isian Data Registrasi Aplikasi Lamikro

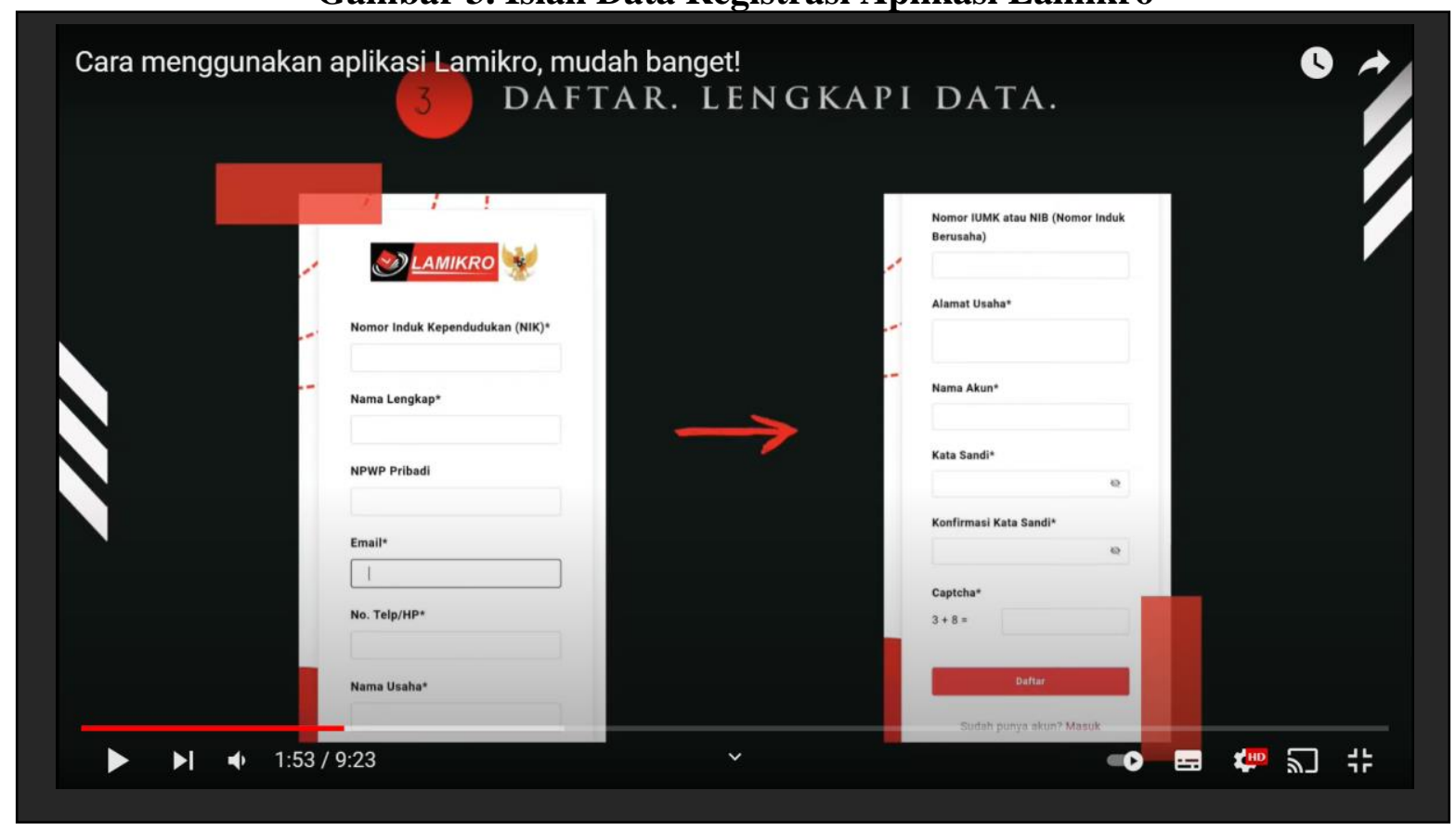

Sumber: Aplikasi Lamikro (2021)

Setelah data registrasi diisi, aplikasi meminta mengisi captcha berupa penjumlahan sederhana. Selanjutnya klik "Daftar" dan akah ada notifikasi dari aplikasia seperti pada Gambar 4.

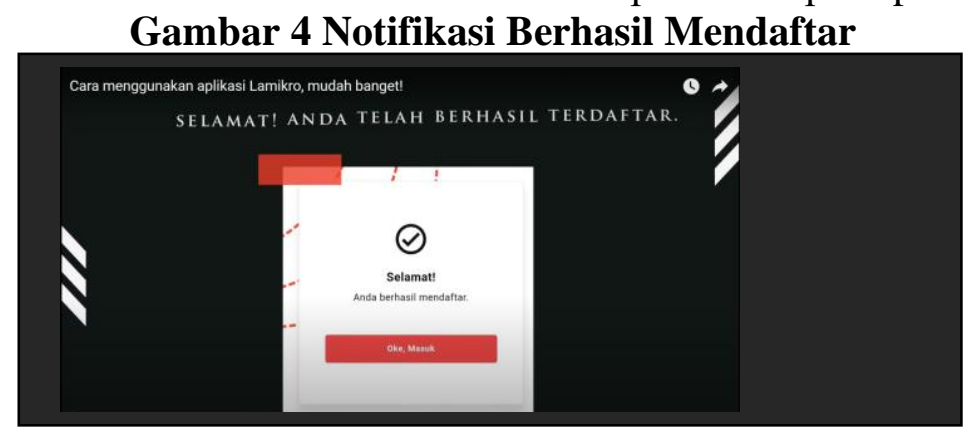

Sumber: Aplikasi Lamikro (2021) 


\section{PENGMASKU}

Volume 2 No. 1, 2022

Selanjutnya klik "Oke, Masuk" dan mengisi data profil usaha yang diminta oleh aplikasi meliputi:

- Sektor Usaha (sudah disediakan pilihan)

- Bidang Usaha (sudah disediakan pilihan)

- Tanggal Pendirian Usaha

- NPWP Usaha

- Kekayaan Usaha (Aset) per Tahun

- Volume Usaha (Omset) per Tahun

- Jumlah Karyawan

- Kapasitas Produksi per Tahun

- Anggota Koperasi

Pengisian data profil usaha ini tidak bertanda * yang berarti bersifat opsional seperti terlihat pada Gambar 5.

Gambar 5. Isi Data Profil Usaha

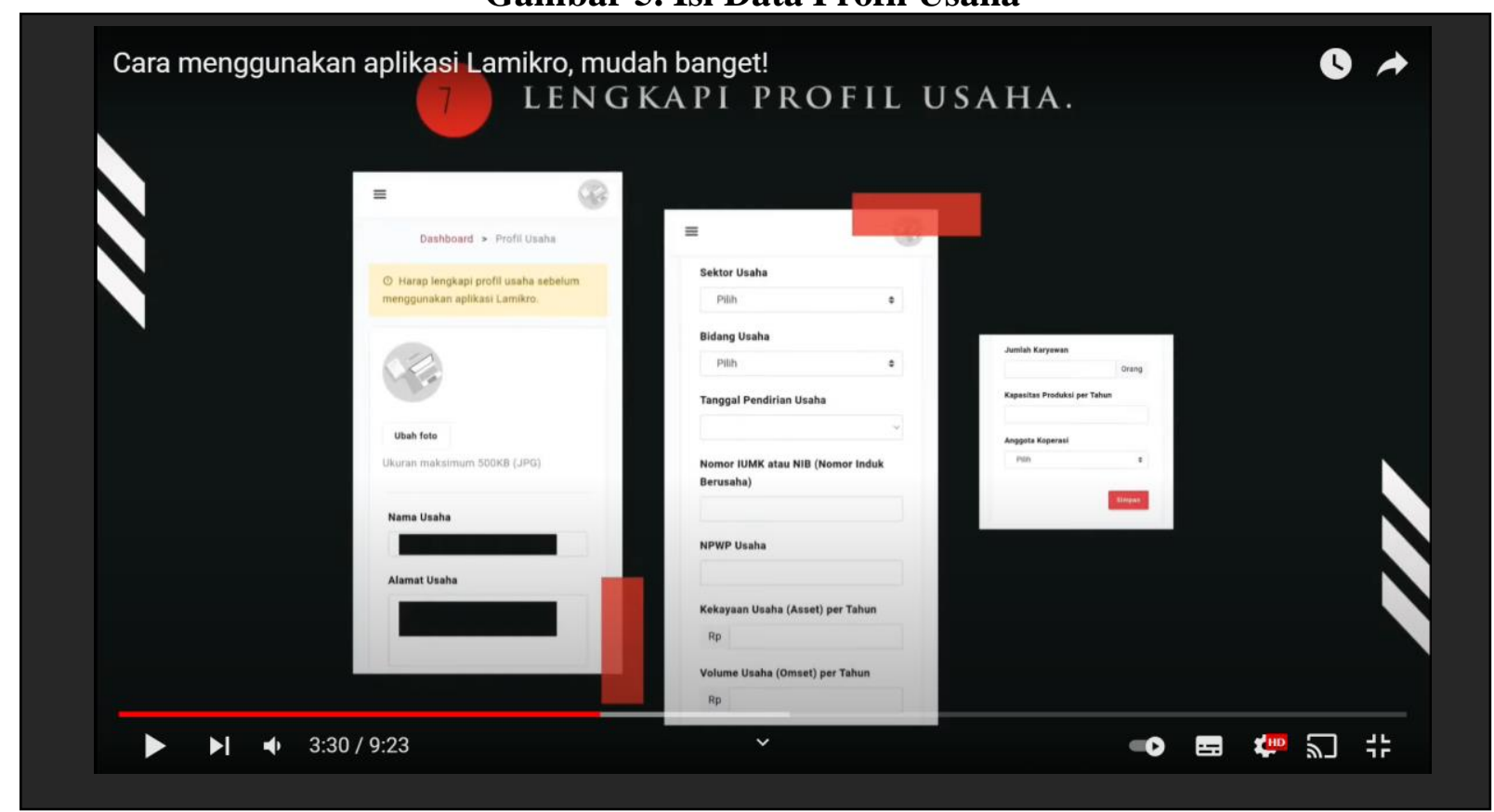

Sumber: Aplikasi Lamikro (2021)

Setelah diklik "Simpan" akan muncul tampilan dashboard aplikasi Lamikro yang berisi menumenu seperti pada Gambar 6. 


\section{PENGMASKU}

Volume 2 No. 1, 2022

Gambar 6. Tampilan Dashboard Aplikasi Lamikro

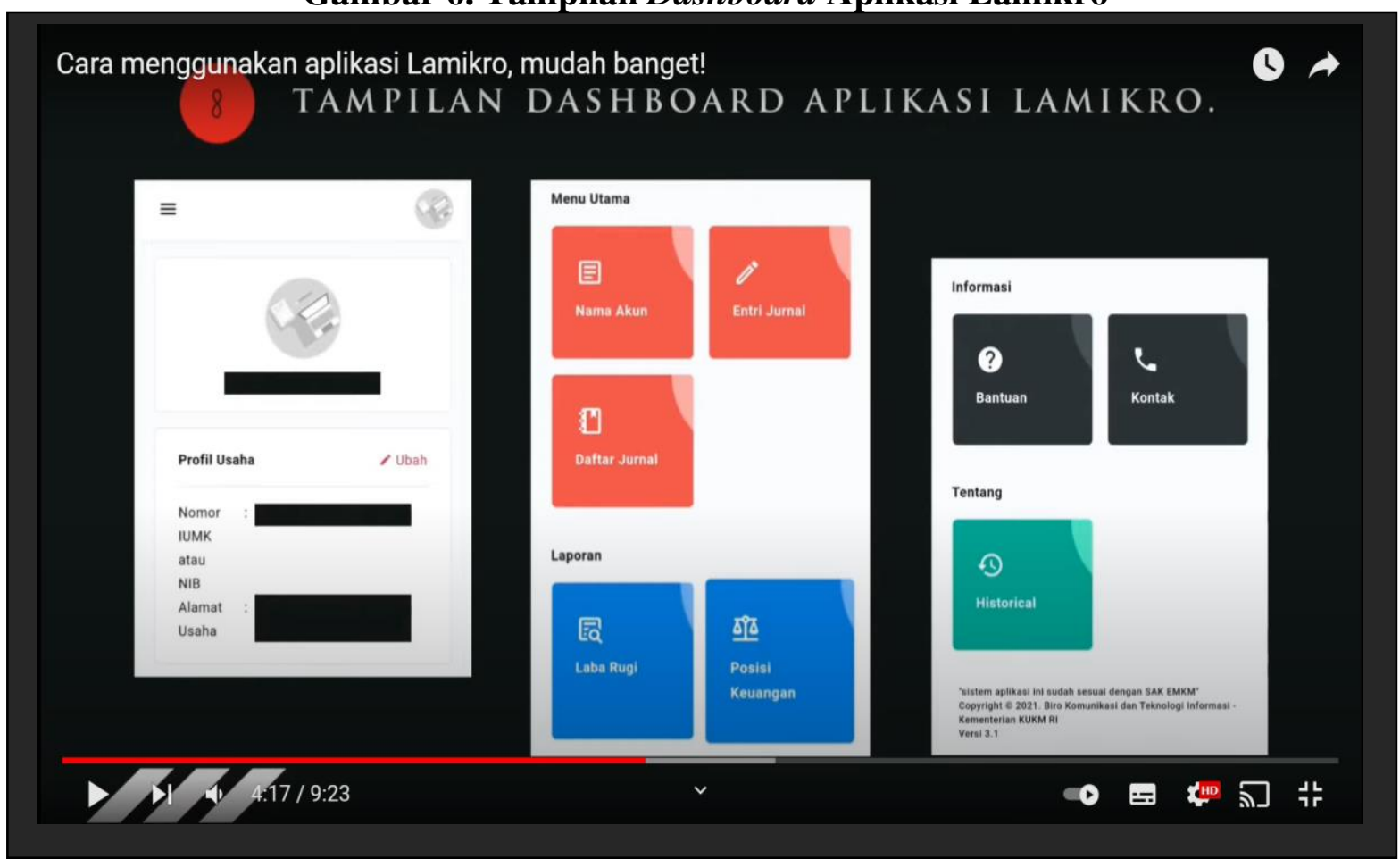

Sumber: Aplikasi Lamikro (2021)

Menu Daftar Akun berisi akun-akun yang digunakan pada laporan laba rugi dan laporan posisi keuangan. Akun-akun ini sudah given dan tidak bisa diubah. Tampilan nama-nama akun disajikan pada Gambar 7.

\section{Gambar 7. Menu Daftar Akun}

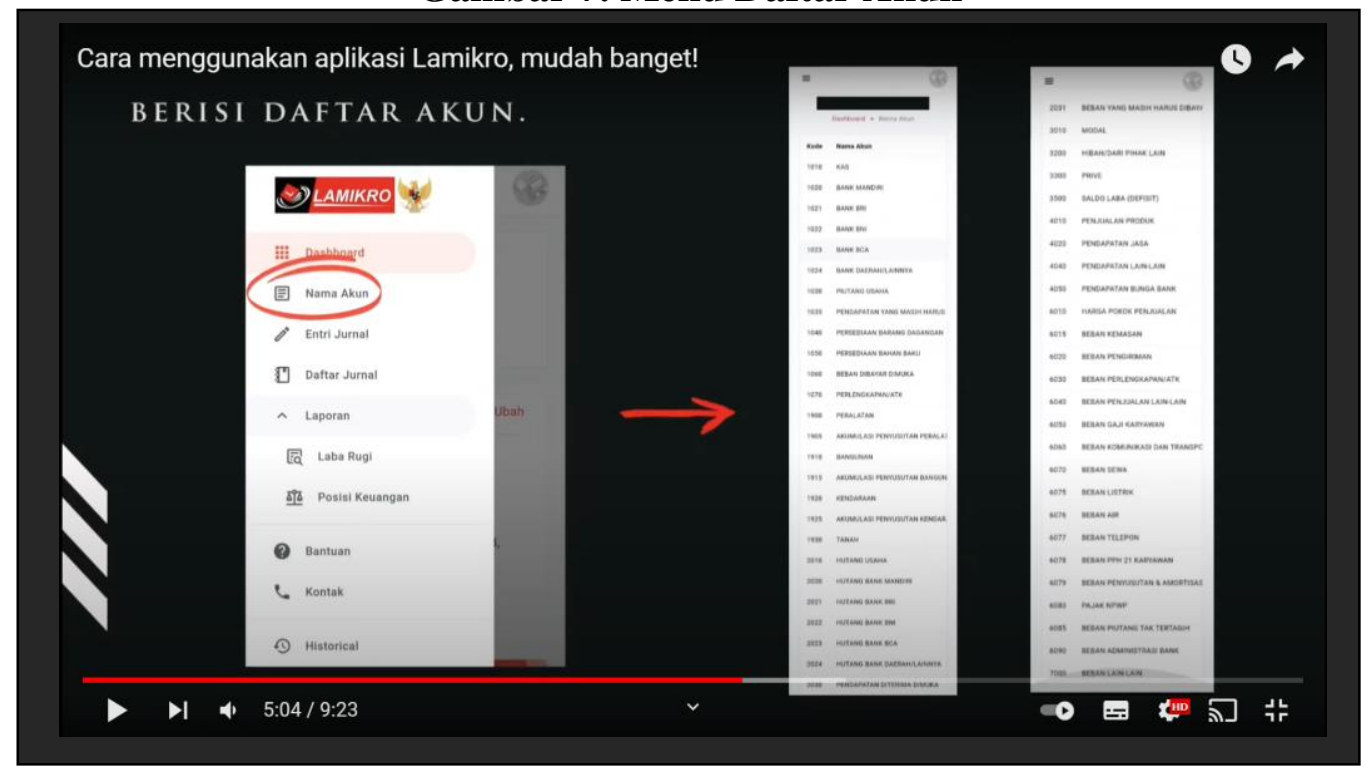

Sumber: Aplikasi Lamikro (2021)

Menu Entri Jurnal digunakan untuk menginput transaksi. Data yang perlu diisi meliputi:

- Tanggal Jurnal

- Jenis transaki (sudah tersedia pilihan)

- Diterima Dari (sudah tersedia pilihan akun-akun)

- Simpan ke (sudah tersedia pilihan akun-akun)

- Nominal 
- Keterangan

Data-data di atas harus diisi kecuali keterangan yang bersifat opsional. Tampilan menu entri jurnal disajikan pada Gambar 8.

\section{Gambar 8. Tampilan Menu Entri Jurnal}

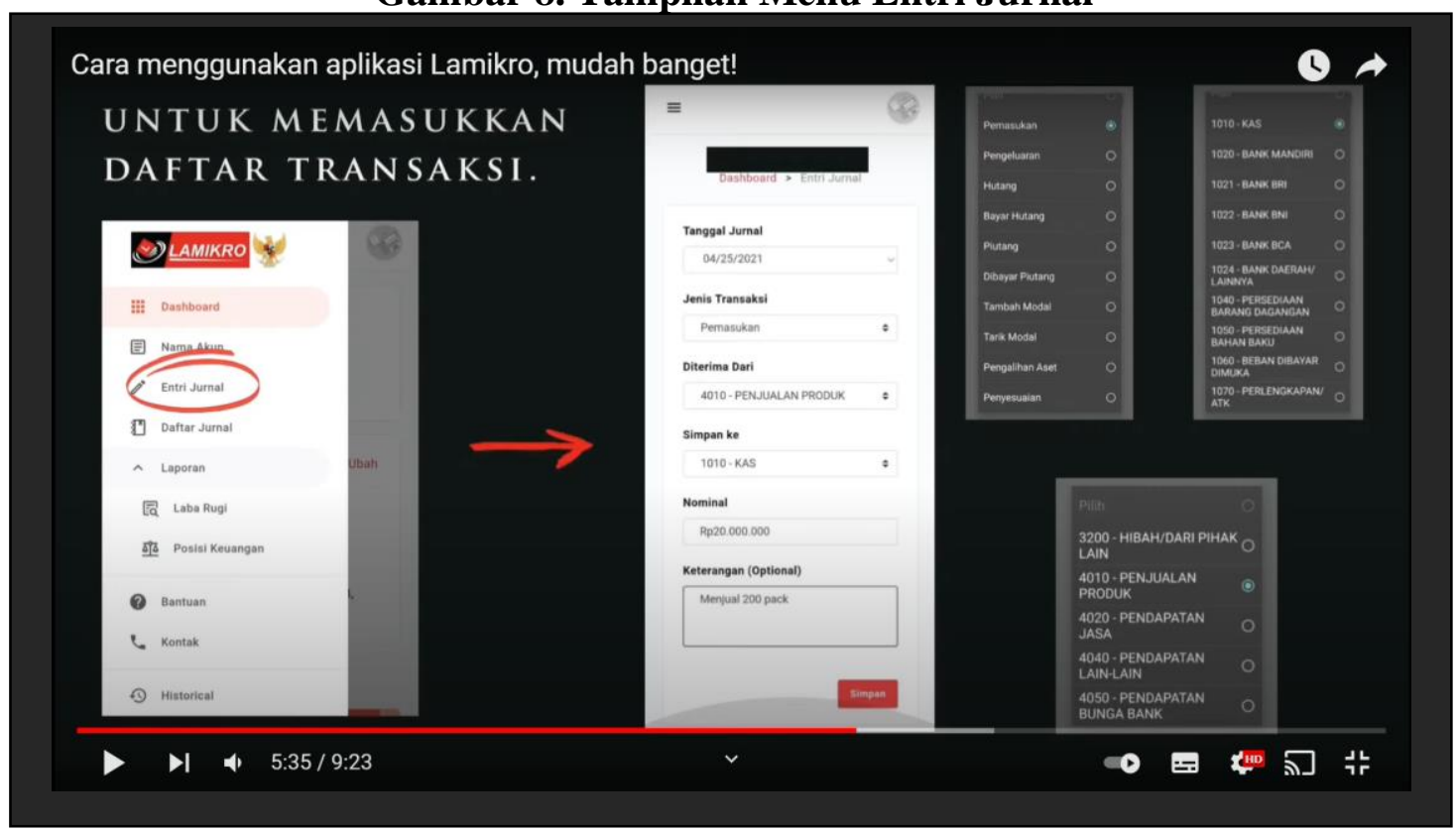

Sumber: Aplikasi Lamikro (2021)

Transaksi-transaksi usaha yang sudah diinput dapat dilihat di menu Daftar Jurnal. Menu ini dilengkapi dengan fitur pencarian jurnal dan fitur menghapus jurnal. Aplikasi Lamikro tidak menyediakan menu mengedit jurnal transaksi yang sudah diinput. Apabila terdapat kesalahan pada jurnal yang sudah diinput maka perbaikannya dengan cara menghapus jurnal yang salah dan menginput ulang transaksi tersebut dengan benar. Tampilan menu Daftar Jurnal disajikan pada Gambar 9.

\section{Gambar 9. Tampilan Menu Daftar Jurnal}

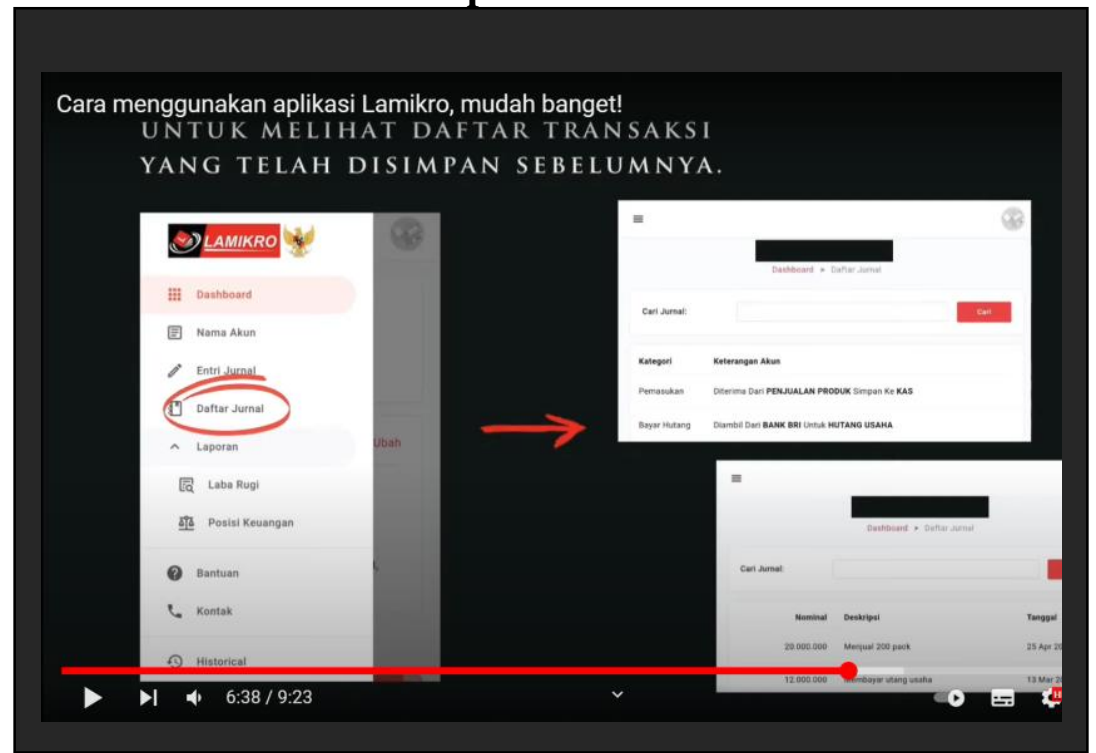

Sumber: Aplikasi Lamikro, diolah (2021)

Pengguna aplikasi Lamikro dapat menampilkan laporan laba rugi setiap saat setelah data transaksi diinput. Laporan laba rugi menampilkan saldo akun-akun pendapatan, total pendapatan, saldo akun-akun beban usaha, total beban usaha, laba/rugi, pajak 0,5\% dari omset, 


\section{PENGMASKU}

Volume 2 No. 1, 2022

dan laba bersih. Pada menu ini ada pilihan periode laporan laba rugi yang akan ditampilkan, bisa per bulan atau per tahun. Menu Laporan Laba Rugi dapat dilihat pada Gambar 10. Menu ini menyediakan Laporan Laba Rugi dengan format pdf. Berdasarkan pengalaman, pengguna aplikasi harus membuka Lamikro.web di telepon genggam atau di laptop. Dengan mengeklik tomboh Unduh Pdf, file laporan laba rugi akan tersimpan di folder Unduhan.

\section{Gambar 10. Menu Laporan Laba Rugi}

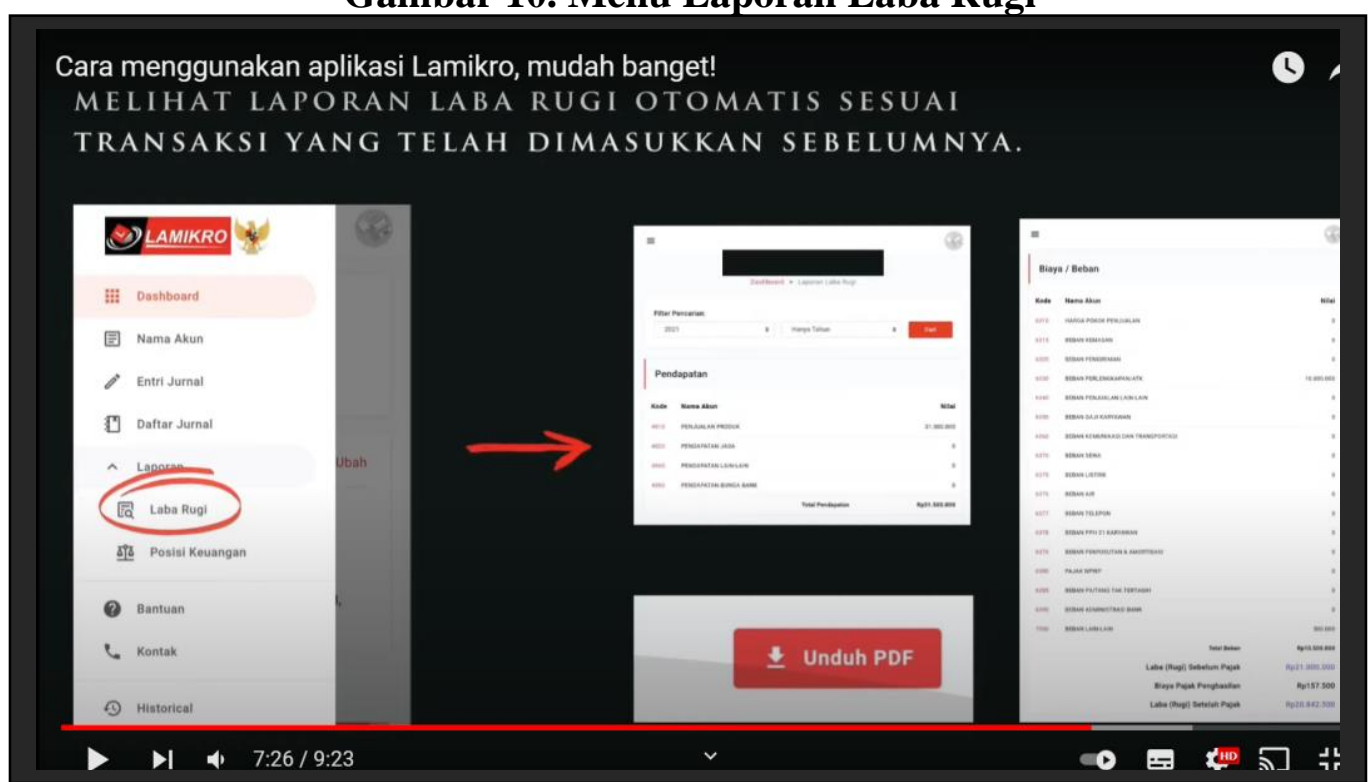

Sumber: Aplikasi Lamikro (2021)

Menu Laporan Posisi Keuangan menyajikan saldo akun-akun asset, total asset, saldo akun-akun kewajiban, total kewajiban, dan modal pemilik. Laporan posisi keuangan bisa diunduh seperti laporan laba rugi. Tampilan menu Laporan Posisi Keuangan tersaji pada Gambar 11.

Gambar 11. Tampilan Menu Lapoan Posisi Keuangan

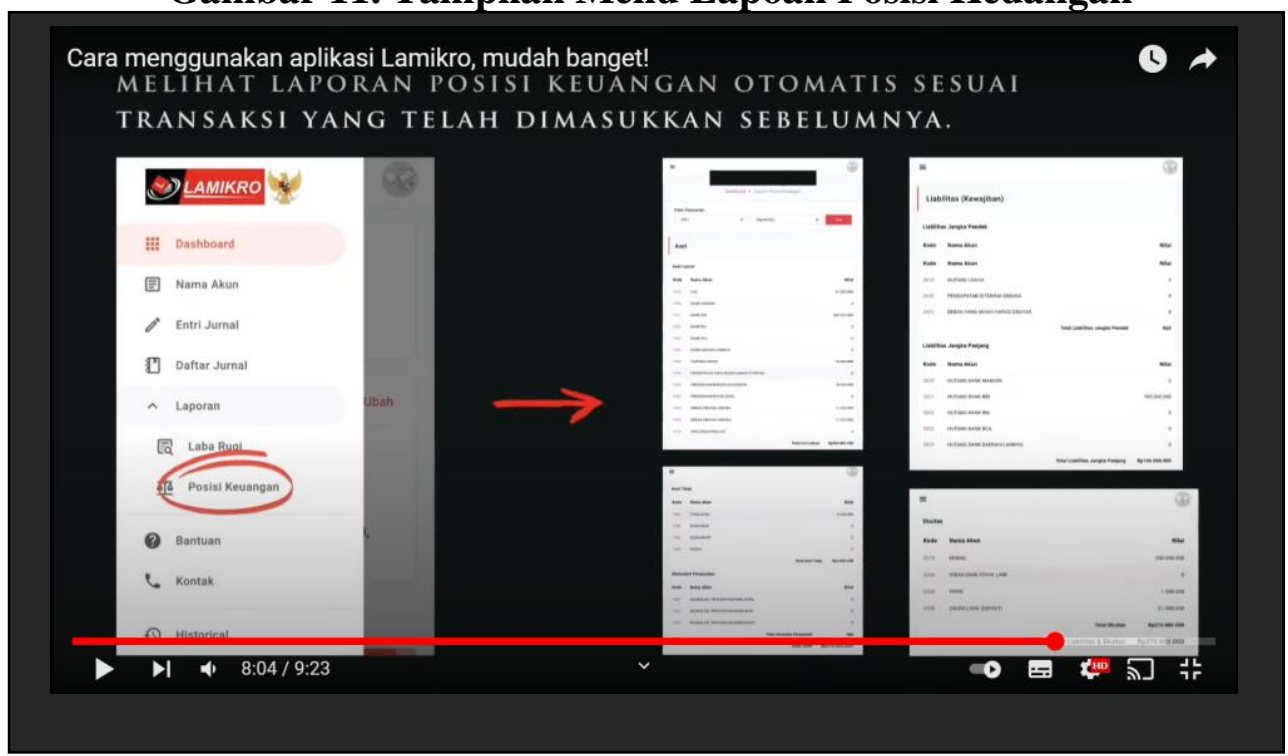

Sumber: Aplikasi Lamikro (2021)

\section{Poster Edukasi}

Luaran kedua berupa poster edukasi dengan judul Aplikasi Lamikro Sebagai Pemberdaya UMKM di Era Digital 4.0. Poster ini berisi beberapa hal:

- Kalimat Motivasi: Menyusun laporan keuangan menjadi mudah dengan Lamikro. Untuk memotivasi UMKM menggunakan Lamikro, Tim Pengmas menyebutkan secara singkat keunggulan Lamikro. 


\section{PENGMASKU}

Volume 2 No. 1, 2022

- Fitur-fitur Lamikro: Entri Jurnal, Daftar Jurnal, Laba Rugi, dan Neraca.

- Manfaat: memonitor aktivitas keuangan UMKM, membuat laporan keuangan lebih, cepat dan efisien, menggantikan metode tradisional pencatatan manual, dan prosedur penganggaran lebih modern.

- QR code yang mengarahkan ke link Youtube video tutorial aplikasi Lamikro.

Poster edukasi diserahkan kepada Gene' Rent Car, UMKM Tangerang Selatan, dan Gangsal Coffee and Drinks, UMKM Bandung. Foto penyerahan poster dapat dilihat pada Gambar 12.

\section{Gambar 12. Foto Penyerahan Poster Edukasi ke UMKM}

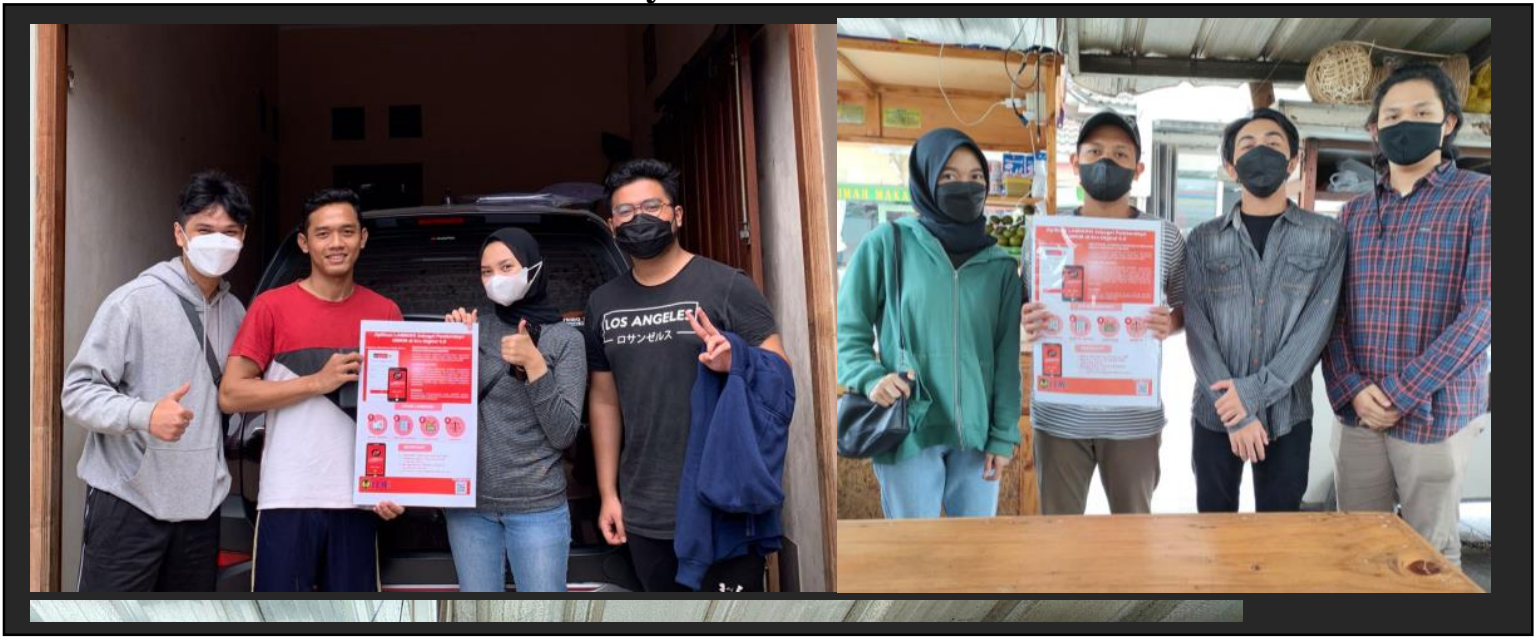

Sumber: Tim Pengmas (2021)

Adapun poster edukasi terlihat lebih jelas pada Gambar 13 .

Gambar 13. Poster Edukasi Lamikro

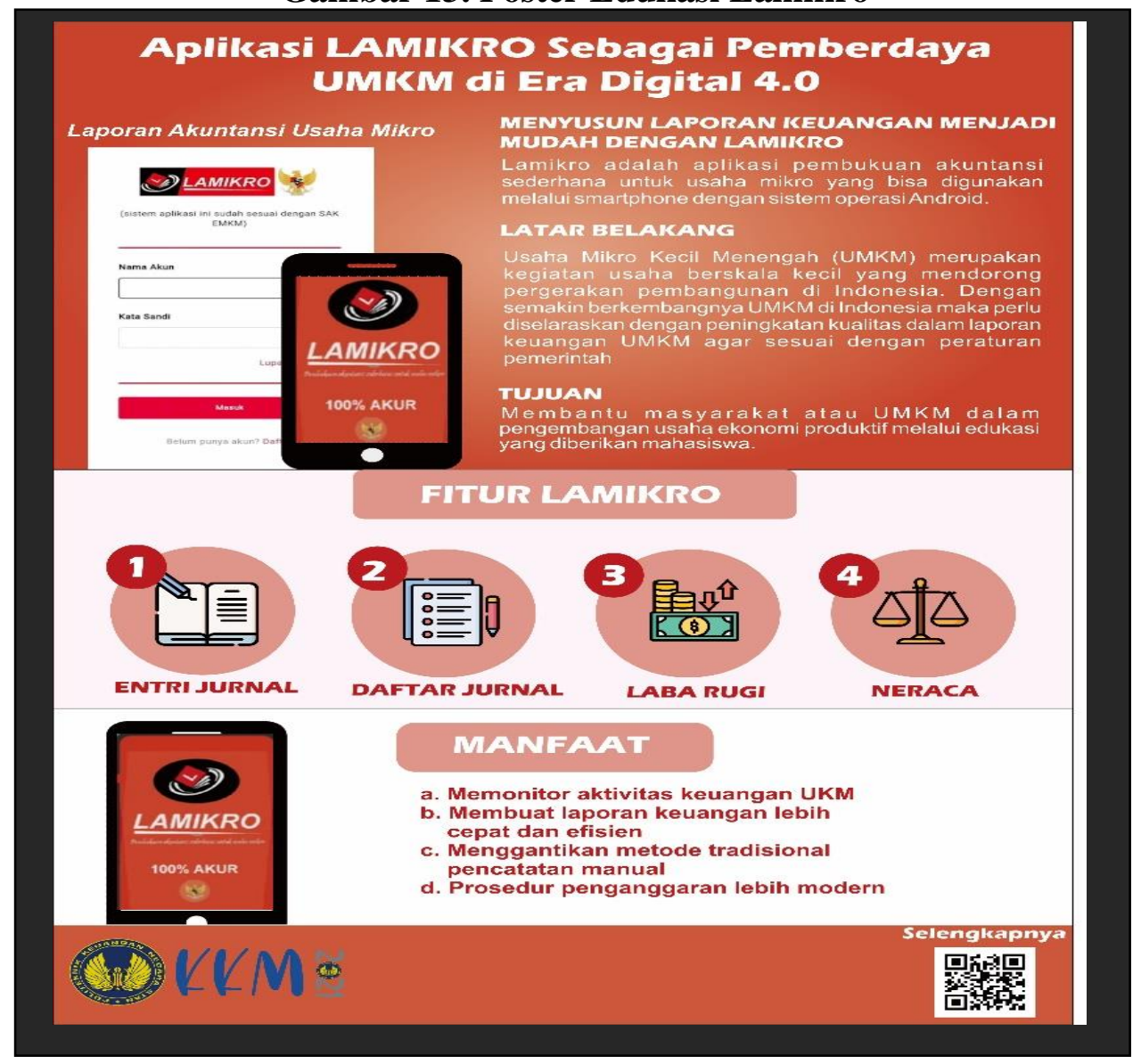




\section{PENGMASKU}

Volume 2 No. 1, 2022

Sumber: Tim Pengmas (2021)

\section{PENUTUP \\ Simpulan}

Peraturan Pemerintah Republik Indonesia Nomor 23 Tahun 2018 tentang Pajak Penghasilan atas Penghasilan dari Usaha yang Diterima atau Diperoleh Wajib Pajak yang Memiliki Peredaran Bruto Tertentu mengamanatkan kepada Usaha Mikro, Kecil, dan Menengah (UMKM) untuk menyusun laporan keuangan sesuai standar yang berlaku dalam waktu paling lambat 7 tahun. Tim pengabdian kepada masyarakat PKN STAN terintegrasi kuliah kerja mahasiswa berinisiatif membantu mengatasi permasalahan tersebut dengan membuat video tutorial dan poster edukasi penyusunan laporan keuangan menggunakan aplikasi Lamikro. Aplikasi Lamikro dipilih karena sederhana dan mudah digunakan oleh pelaku UMKM. Video tutorial diunggah di Youtube agar bisa dimanfaatkan oleh UMKM secara luas. Poster edukasi diserahkan kepada Gene' Rent Car, UMKM Tangerang Selatan, dan Gangsal Coffee and Drinks, UMKM Bandung.

\section{Saran}

Untuk kegiatan pengabdian kepada masyarakat yang akan datang, disarankan untuk melakukan pendampingan penyusunan laporan keuangan menggunakan apliasi Lamikro secara luring untuk membantu pelaku UMKM yang belum membuat laporan keuangan dan belum mengakses video tutorial yang sudah diunggah di Youtube.

\section{DAFTAR PUSTAKA}

Kemenkop UKM. (2019). Pelaku UMKM Didorong Kelola Keuangan Dengan Lebih Baik. Kemenkop KMM. https://kemenkopukm.go.id/read/pelaku-umkm-didorong-kelolakeuangannya-dengan-lebih-baik

Kemenkop UKM. (2021). Perkembangan Data Usaha Mikro, Kecil, Menengah, dan Usaha Besar. In Www.Depkop.Go.Id (Vol. 2000, Issue 1). http://www.depkop.go.id/data-umkm

Kominfo. (2018). Lamikro, Aplikasi Laporan Keuangan Sederhana Untuk Usaha Mikro. Kominfo.Go.Id. https://www.kominfo.go.id/content/detail/13065/lamikro-aplikasilaporan-keuangan-sederhana-untuk-usaha-mikro/0/artikel_gpr

PP No. 23, Peraturan Pemerintah No. 23 Tahun 20181 (2018). https://www.pajak.go.id/sites/default/files/2019-05/PP Nomor 23 Tahun 2018.pdf

UKM Indonesia. (n.d.-a). Izin Usaha Mikro Kecil (IUMK). https://www.ukmindonesia.id/bacaizin/1486

UKM Indonesia. (n.d.-b). Nomor Induk Berusaha (NIB). https://www.ukmindonesia.id/bacaizin/1487

www.kompas.com. (2018). Masih Banyak Pelaku UMKM "Buta" Akuntansi. Kompas.Com. https://money.kompas.com/read/2018/08/30/144531526/masih-banyak-pelaku-umkmbuta-akuntansi 


\section{PENGMASKU}

Volume 2 No. 1, 2022

\section{LAMPIRAN}

\section{Tangkapan Layar Diskusi Penentuan Luaran Pengmas Terintegrasi KKM}

Zoom Meeting

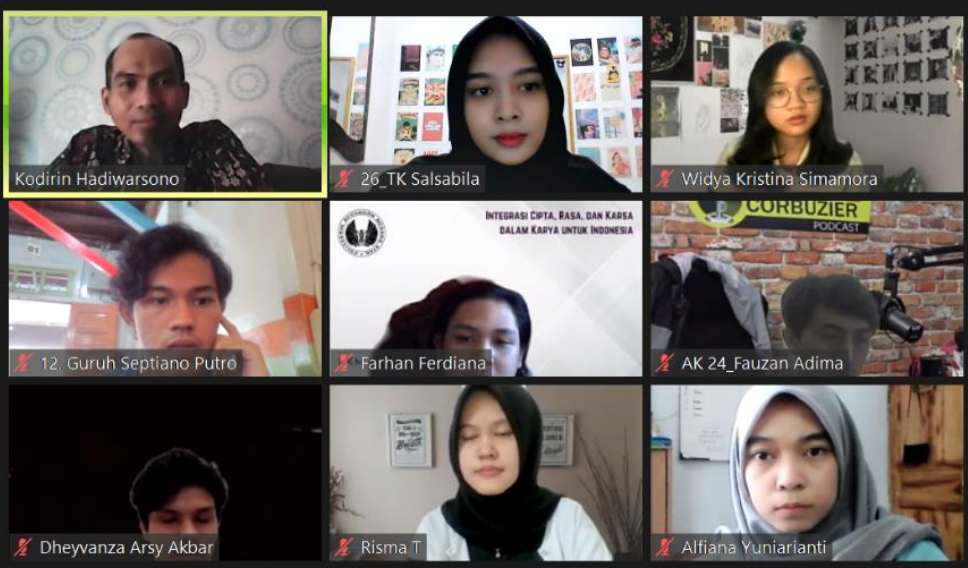

Hizkia Elhagios...

mala

Sumber: Tim Pengmas (2021) 